\title{
Barotropic eastward currents in the western Gulf of Lion, north-western Mediterranean Sea, during stratified conditions
}

\author{
A. Petrenko ${ }^{\text {a,* }}$, C. Dufau ${ }^{\mathrm{b}, 1}$, C. Estournel ${ }^{\mathrm{b}}$ \\ a Aix-Marseille Université, CNRS, LOB-UMR 6535, Laboratoire d'Océanographie Physique et de Biogéochimie, OSU/Centre d'Océanologie de Marseille, Marseille, Francev \\ b Pôle d'Océanographie Côtière, Laboratoire d'Aérologie, Laboratoire d'Etudes en Géophysique et Océanographie Spatiales, Toulouse, France
}

The circulation of the Gulf of Lion, a large continental shelf north of the western basin of the Mediterranean Sea, is complex and highly variable. During stratified conditions, unexpected barotropic eastward currents can be detected, mostly in the western part of the gulf. Care is given to retrieve inertial oscillations when necessary. The primitive-equation free-surface model Symphonie is used to investigate the processes which can generate and influence these eastward currents. Three main wind forcing create these barotropic eastward currents: northwesterlies channelled in the western part of the gulf, northwesterlies and north winds both homogeneous throughout the gulf. In the first case, the wind stress curl of the channeled northwesterlies generates an elongated cyclonic circulation in the western part of the Gulf of Lion. The southern part of this cyclonic circulation is a barotropic eastward current, detected west of longitude $4.5^{\circ} \mathrm{E}$. In the second case, a homogeneous northwesterly wind creates an intrusion of the along-slope geostrophic current on the shelf, generating a strong coastal jet going northward above Cap Creus. In stratified conditions, intrusion at this western end of the continental shelf only occurs during this type of wind forcing. The coastal jet goes north then detaches itself from the coast and goes eastward, north of the $100 \mathrm{~m}$ isobath. In the third case, a homogeneous north wind creates an eastward current which occupies the whole shelf north of latitude $43^{\circ} \mathrm{N}$. The first two cases are studied in more details since cruise data corroborate the model simulations. The striking characteristic of these eastward currents is that they are barotropic despite the stratified conditions. Otherwise, their amplitude and exact locations are slightly different for the different cases of circulation. These eastward currents probably have an impact on the residence time of water masses in the Gulf of Lion, and hence on the total water budget of the gulf, as well as on primary production and biogeochemical fluxes.

\section{Introduction}

The circulation of the Gulf of Lion (hereafter, GoL), a large continental shelf north of the western basin of the Mediterranean Sea, is complex and highly variable. As explained by Millot (1990), it is influenced by the variability of the general circulation, the wind forcing, the coastline and bathymetry,

\footnotetext{
* Corresponding author. Tel.: +33 4918290 61; fax: +33 491821991. E-mail addresses: petrenko@univmed.fr (A. Petrenko), claire.dufau@cls.fr (C. Dufau), claude.estournel@aero.obs-mip.fr (C. Estournel).

1 Present address: CLS Space Oceanography Division, Parc Technologique du Canal, Ramonville Saint-Agne, France.
}

the fresh water inputs, the stratification and the potential formation of dense water in winter.

The general circulation in the western basin of the Mediterranean Sea consists in a large cyclonic circulation following the coast around the whole basin. The northern part of the cyclonic circulation consists of the Mediterranean Northern Current (Millot, 1990, 1992). This Northern Current (NC) flows along the continental slope bordering the GoL (Fig. 1). In winter, the NC is narrow (<30 km), deep (>250 m), intense (flux around 1.5-2 Sv), close to the coast and can develop important mesoscale meanders (Millot, 1999; Petrenko, 2003). In summer, the NC is wider $(\sim 35 \mathrm{~km})$, more shallow $(<200 \mathrm{~m})$, generally less intense and further 
from the coast than in winter. The NC can intrude on the continental shelf at various places, on the eastern side (Petrenko et al., 2005), at the center (Estournel et al., 2003), and, more rarely, at the south-western side (as shown in Section 3.1.2).

Fresh water inputs come from eight rivers, in decreasing annual flux order: Rhone, Herault, Aude, Orb, Têt, Tech, Vidourle and Agly (Bourrin and Durrieu de Madron, 2006). The major one, the Rhone river, has an annual flux which amounts to about 17.5 times the sum of the annual fluxes of the following 3 rivers (Herault, Aude, Orb) and about 135 times the flux of the 5th one, the Têt (Ludwig et al., 2003).

In the Gulf of Lion, the shelf circulation is strongly influenced by the winds. At all seasons the most characteristic atmospheric disturbances are created by a low pressure cell located in the Gulf of Genoa (Fig. 1A) while a high pressure area is located on the Atlantic Ocean or part of Spain. The prevailing winds are northwesterlies or northly winds, with strength up to 45 knots. These winds are called Tramontane (northwesterly, sometimes westerly) when their acceleration channel is located between the Pyrénées and the Massif Central and Mistral (generally north wind) when they are generated in the Rhone river channel. Northwesterlies and north winds can create upwellings or downwellings, when the coastline is straight and in the favourable direction. Millot (1990) determined six upwelling zones with three corresponding surface anticyclonic circulations (Fig. 1B). Millot indicated that the bottom currents, induced by northwesterlies, are north-eastward. Hence, a simplified vision of the circulation in the GoL is sometimes used, consisting in a mainly south-westward surface flow (apart for the western portions of the anticyclonic cells), with a north-eastward counter-current at the bottom. But, in reality, the circulation of the GoL is extremely more complex than this.

Shelf-edge currents, opposite to the along-slope circulation, can be called "counter-currents". Coastal circulations elsewhere in the world do exhibit such features. Some coastal counter-currents are buoyancy-driven (Masson and Cummins, 1999); others are both wind- and pressure-driven (Frouin et al., 1990; Relvas and Barton, 2002). Sometimes, an offshore current generates a pressure distribution creating a shelf counter-current (Hetland et al., 2001). In order to have more comparable geographical environments, examples of shelves similar to the GoL were looked for. Two main examples were found: the north-western shelf of the Black Sea, bordered by the Rim Current; and the Gulf of Papua, bordered by the Coral Sea Coastal Current. In both cases, the shelf circulation was found to be mainly wind-driven with complex flow patterns (Oguz and Besiktepe, 1999), even despite a very different haline statification in the case of the Gulf of Papua (Wolanski et al., 1995). Nonetheless, in all these studies, the curl of the wind stress was not taken into account, while it is crucial as will be shown in this paper.

Winter circulation features in the Gulf of Lion have been studied in details and very well reproduced by modelling studies (Dufau-Julliand et al., 2004; Estournel et al., 2003; Petrenko, 2003). During the winter, Petrenko (2003) noticed an eastward current on the shelf but made the hypothesis that it could be due to the numerous intrusions of the NC in the Gulf of Lion. During the summer, eastward currents have been observed both in the western and eastern parts of the GoL (Petrenko, 2003). In the western part of the GoL, Petrenko interpreted this eastward current to be the southern loop of an elongated cyclonic gyre created by northwesterlies. But this was not demonstrated since the paper was purely descriptive. Thunus (1996) showed that, during calm summer periods, an eastward current (the northern branch of an anticyclonic circulation) crossed the western part of the GoL, as summarized by Durrieu de Madron et al. (2000). Hence further study is needed to be done in order to best describe the various types of eastward currents encountered in the GoL in stratified conditions, as well as their respective forcing.

The presence of these eastward currents could have non negligible repercussions on the water residence time and primary production of the shelf, and hence on total biogeochemical budgets of the Gulf of Lion as well as fishery activities, which are important in the Gulf of Lion.

The present study concentrates on the generating processes of the eastward currents present on the western continental shelf of the Gulf of Lions during stratified conditions. The study focuses on eastward currents detached from the coast and stresses the importance of the curl of the wind stress. The 3D primitive-equation Symphonie model (Estournel et al., 1997) is used, both with academic and realistic simulations, in order to show that there are three main generating mechanisms to these eastward currents.

\section{Materials and methods}

\subsection{Wind data}

In order to obtain synoptic values throughout the GoL, the wind simulated by the French meteorological model Aladin is used. Good agreement between Aladin and in situ measured winds has been previously found (Petrenko et al., 2005). To simplify the reading of this paper, we will refer to northwesterlies as NW and to north winds as $\mathrm{N}$ winds. When a wind blows throughout the whole gulf, it is referred to as "homogeneous". When it blows in a section of the gulf, it generally has a main core along a given direction and, hence, is referred to as "channelled" in a specific direction. In this latter case, the wind stress curl is not nil. In both cases, the wind is described by its direction (in degrees clockwise from the north) and its lateral extent (for example, $1 / 2$ or entire $\mathrm{GoL})$; its temporal variations are indicated in Table 1.

\subsection{Current data}

This study has compiled horizontal currents measured throughout the gulf during a dozen oceanographic cruises (Moogli and Sarhygol) done between 1998 and 2001. Details on the ADCP data treatment can be found in Petrenko et al. (2005) and in Petrenko (2003). During stratified conditions, eastward currents were observed on the western side of the continental shelf during Moogli 2 (June 1998), Sarhygol 2 (April 2000), Sarhygol 3 (June 2000) and Sarhygol 8 (June 2001) (Table 1).

Tests need to be done systematically to make sure that the observed eastward currents are not just temporary features, such as inertial currents. Indeed, stratified conditions add a level of difficulty in the analysis of current data due to the potential variability of the mixed layer depth and presence of inertial oscillations, as stressed by Millot (1990). The inertial 

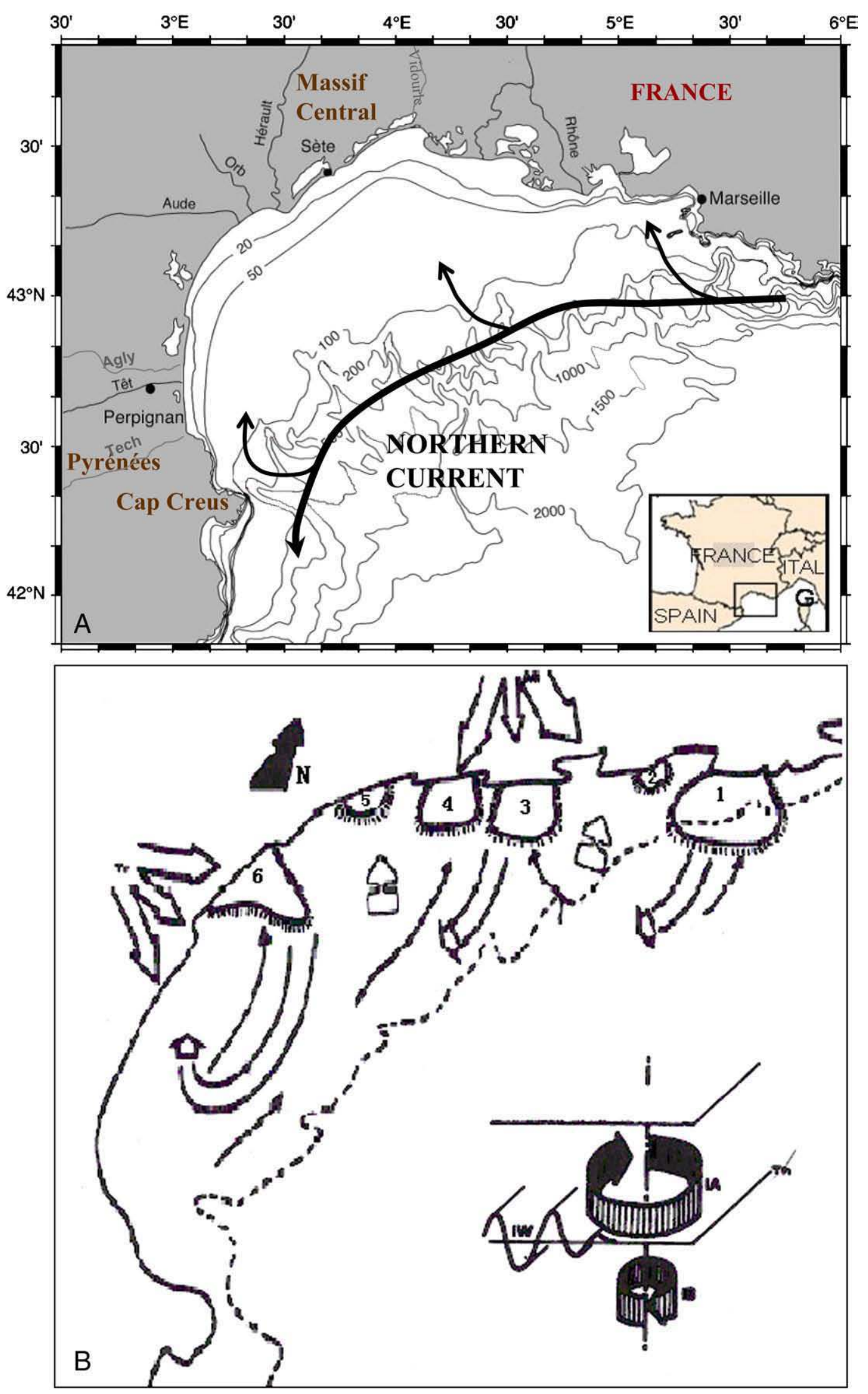
Table 1

This table provides wind data at the given dates

\begin{tabular}{|c|c|c|c|c|c|}
\hline \multirow[t]{2}{*}{ Cruise name } & \multicolumn{5}{|l|}{ Wind data } \\
\hline & Period & Direction & Description & Extent & Strength \\
\hline \multirow[t]{2}{*}{ Moogli 2 A } & June 7,6 h-15 h & $315^{\circ}$ & Channelled NW & $1 / 2$ GoL West & Strong \\
\hline & June 7,18 h-June 8 & $320^{\circ}$ & Homogeneous NW & GoL & Strong \\
\hline- & June $12-13$ & $310^{\circ}$ & Homogeneous NW & GoL & Very strong \\
\hline Moogli 2 B & June $14-15$ & $295^{\circ}$ & Channelled East wind & 1/2 GoL East & Weak \\
\hline \multirow[t]{2}{*}{ Sar 2} & April 23-25, $6 \mathrm{~h}$ & $300^{\circ}$ & Homogeneous NW & $\mathrm{GoL}$ & Strong \\
\hline & April 25, 9 h - April 26 & $120^{\circ}$ & Homogeneous E. & GoL & Weak \\
\hline \multirow[t]{2}{*}{ Sar 3} & June $12-13$ & $310^{\circ}$ & Channelled NW & 1/2 GoL West & Strong \\
\hline & June $14-15$ & $320^{\circ}$ & Channelled NW & 1/2 GoL West & Weak \\
\hline \multirow[t]{2}{*}{ Sar 8} & June $10-12$ & $310^{\circ}$ & Homogeneous NW & GoL & Strong \\
\hline & June $13-15$ & - & Variable & GoL & Weak \\
\hline
\end{tabular}

In bold are indicated the wind forcing responsible for the measured eastward currents. The direction is the one from which the wind comes. Strong winds blow at speeds higher than $10 \mathrm{~m} \mathrm{~s}^{-1}$ with peaks higher than $15 \mathrm{~m} \mathrm{~s}^{-1}$ (very strong winds are superior to $20 \mathrm{~m} \mathrm{~s}^{-1}$ ) while weak winds blow below $10 \mathrm{~m} \mathrm{~s} \mathrm{~s}^{-1}$.

currents are not always easy to localize. They have to be retrieved from the data in order for the detection of eastward currents to be reliable. During the cruises listed above, the water column was stratified with, generally, a sharp thermocline. To analyse the influence of the inertial currents, the hypothesis is made that an inertial oscillation (IO) is a twolayer baroclinic process. A simple analytical formula (sinusoïdal function at the Coriolis frequency) is used to model IOs. The motion of a pure IO is rotating clockwise and has a $180^{\circ}$ phase shift between the upper layer and the lower one. This section is dedicated to the choice of representative depths for the surface and deeper layers and to the treatment and removal of IOs.

Choosing representative depths requires a detailed analysis of the measured temperature profiles (CTDs or XBTs) and of the vertical sections of currents. Methods to detect the presence of IOs include: phase unwrapping (Chereskin et al., 1989; Petrenko, 2003) and overlapping of sinusoïds to currents' differences: the currents measured in the upper layer minus the current measured in the lower layer (this difference inducing the retrieval of barotropic currents). Once the IOs located, systematic filtering methods were tested; but, due to the spatial and temporal variability of the current measurements, of the mixed layer depth, of the IOs themselves, and probably also due to some filter aliasing, these methods did not always bring reliable results. Hence, the "filtering" used in this study consists in retrieving the sinusoïds that fit the closest to the data. This approach is further detailed for one cruise.

During Sarhygol 2 (April 24, 17:00-April 26, 17:30, 2000), the IO analysis shows that the temporal evolution of one unique sinusoïd IO is in agreement with all the currents measured along the ship trajectory between stations 2 and 10 (Fig. 2). It is probably the strong NW, which blew before and at the beginning of the cruise (Table 1 ), that generated the IO present throughout the western GoL. The effect of this IO on the current is complicated by the fact that, not only the IO varies with time, but the depth of the thermocline varies throughout the gulf. Hence, at the same depth but different locations, one can feel the effect of either the upper layer IO or of the lower layer one. Indeed, the thermocline is at $15 \mathrm{~m}$ in the most northern parts of the GoL but deepens to $40 \mathrm{~m}$ in the shelf center. The IO amplitude is $\sim 10 \mathrm{~cm} / \mathrm{s}$ in the top layer, and $\sim 4 \mathrm{~cm} / \mathrm{s}$ in the lower layer ( $\sim 2.5$ times thicker than the upper layer). It is possible to separate IO and currents by showing the currents at a depth shallow enough to always be in the upper layer (e.g., $12 \mathrm{~m}$ ), and, reciprocally, in the deep layer (e.g., $48 \mathrm{~m}$ ), as is done in Fig. 3. The surface inertial currents are directed southwest when measured at station 2 (Fig. 3B and Table 2). Then they gradually rotate clockwise, at the Coriolis period of about $17.5 \mathrm{~h}$ at the GoL latitude, along the cruise trajectory which was carried out following increasing station numbers (these numbers are indicated on Fig. 2C). Hence, between stations 3 and 4, the surface inertial currents are westward; between 4 and 5 north-westward, between 5 and 6 northward then eastward, etc (Fig. 3B); and in the opposite direction in the deep layer (Fig. 3E). Along the meridional transects 3-4 and 7-8, the measured currents in the top layer do not exhibit an eastward component since inertial currents are opposed to it (Fig. 3A and B). Whereas, in the northern portion of transects 5-6, the eastward component of the measured current is increased by the inertial current. The situation is obviously opposite at depths below the thermocline. Indeed, below the thermocline, the eastward current is reinforced by the inertial current along transects 3-4 and 7-8, while diminished in the northern portion of transects 5-6 (Fig. 3D and E). Once the IO contribution is retrieved, the eastward current is present in the western part of the GoL (Fig. 3C and F).

In the rest of the paper, IOs have been either retrieved or filtered out. Hence, hereafter the term 'eastward current' is used only for currents determined not to be inertial currents.

\section{Observed eastward currents in the Gulf of Lions}

During stratified conditions, once the inertial oscillations have been filtered, unexpected strong barotropic eastward currents are detected, about the $100 \mathrm{~m}$ isobath, on the shelf of

Fig. 1. A) Map of the Gulf of Lion, located in the north-western Mediterranean Sea. A schematic path of the Northern Current (NC) is represented by the black arrow (width not at scale), with its potential intrusions on the shelf. The letter G, in the map inserted at the top left corner, indicates the Gulf of Genoa; B) Schematic representation of the phenomena induced by the winds (Mi, Mistral; Tr, Tramontane): the six upwelling zones (1-6), the horizontal circulations in the surface (obvious: $₹$ more or less hypothetical: $\mathfrak{\square}$ ) and bottom $(\uparrow)$ layers, the out of phase oscillatory currents in the layers above (IA) and below (IB) the thermocline (Th) and the internal waves (IW) at the inertial period (reprinted from Millot, C., 1990, Cont. Shelf Res.). 

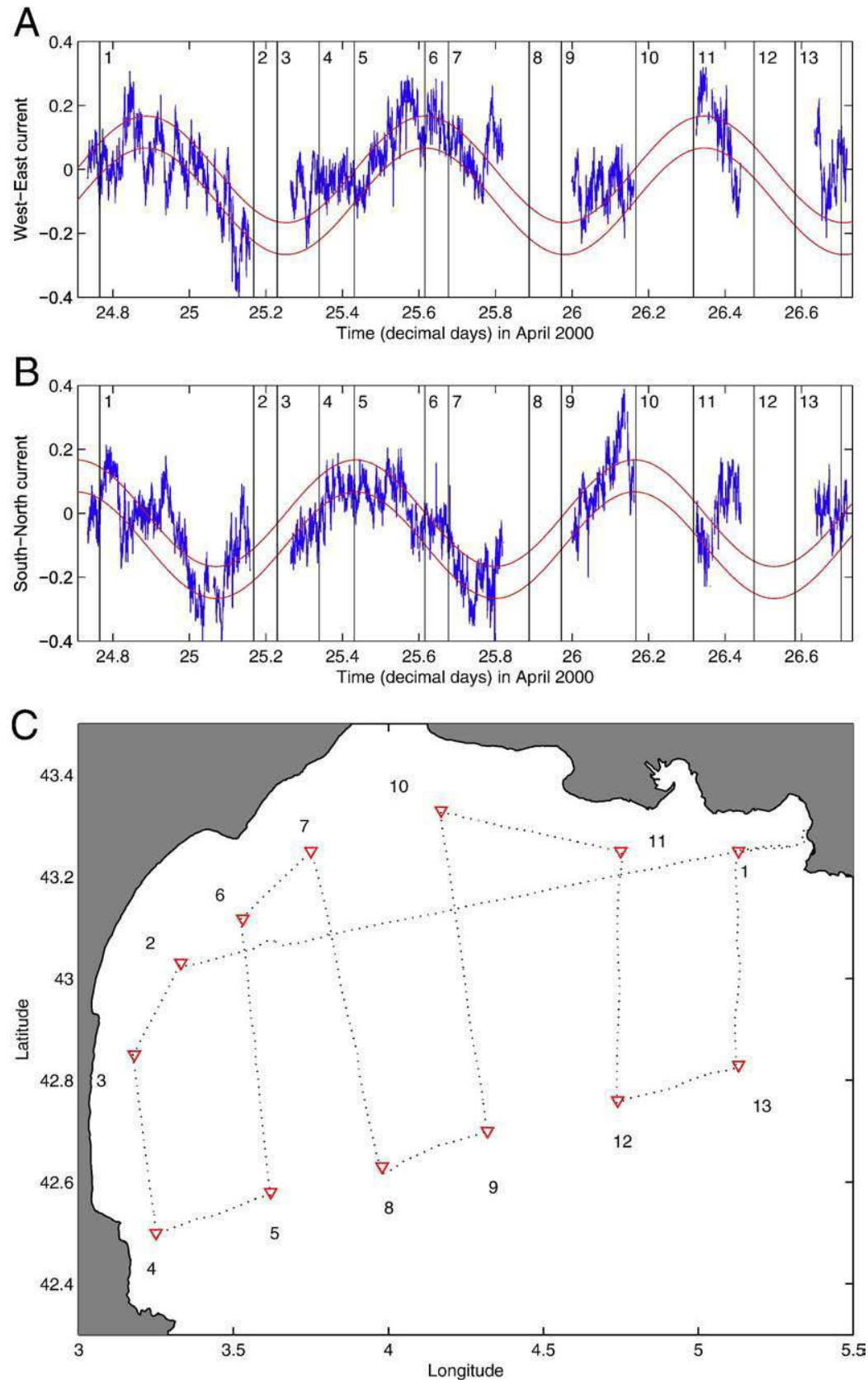

Fig. 2. Time series of the ADCP current differences between two depths, in $\mathrm{m} / \mathrm{s} \mathrm{A}) u(12 \mathrm{~m})-u(48 \mathrm{~m}), u$ being the west-east (+ east) component of the horizontal current and B) $v(12 \mathrm{~m})-v(48 \mathrm{~m}), v$ being the south-north (+ north) component during Sarhygol 2, April 2000. A sinusoid at the Coriolis frequency, representing the inertial oscillation is added to A and shifted by $\pi / 2$ in B. The numbered vertical bars indicate when the RV passed by the stations shown on the C) map of the cruise trajectory.

the western GoL. The current data, limited to three cruises, are presented in their chronological order.

\subsection{Moogli 2}

During the first period (June 6-8, 1998) of Moogli 2 (hereafter referred to as Moogli 2A), the thickness of the mixed layer is relatively constant, ranging from 10 to $20 \mathrm{~m}$. There is no significant influence of inertial currents on the eastward current in the western side of the GoL. The eastward current corresponds to the southern side of a cyclonic circulation (Fig. 4A). The maximum speed of this eastward current is $21 \mathrm{~cm} / \mathrm{s}$, measured at $24 \mathrm{~m}$ depth (Table 3).

During the second period (Moogli 2B: June 14-15, 1998), after the strong storm of homogeneous NW (Table 1), inertial currents are present in the central part of the shelf but do not hide the main circulation features on the western and northern sides of the GoL. There is a strong northward coastal 

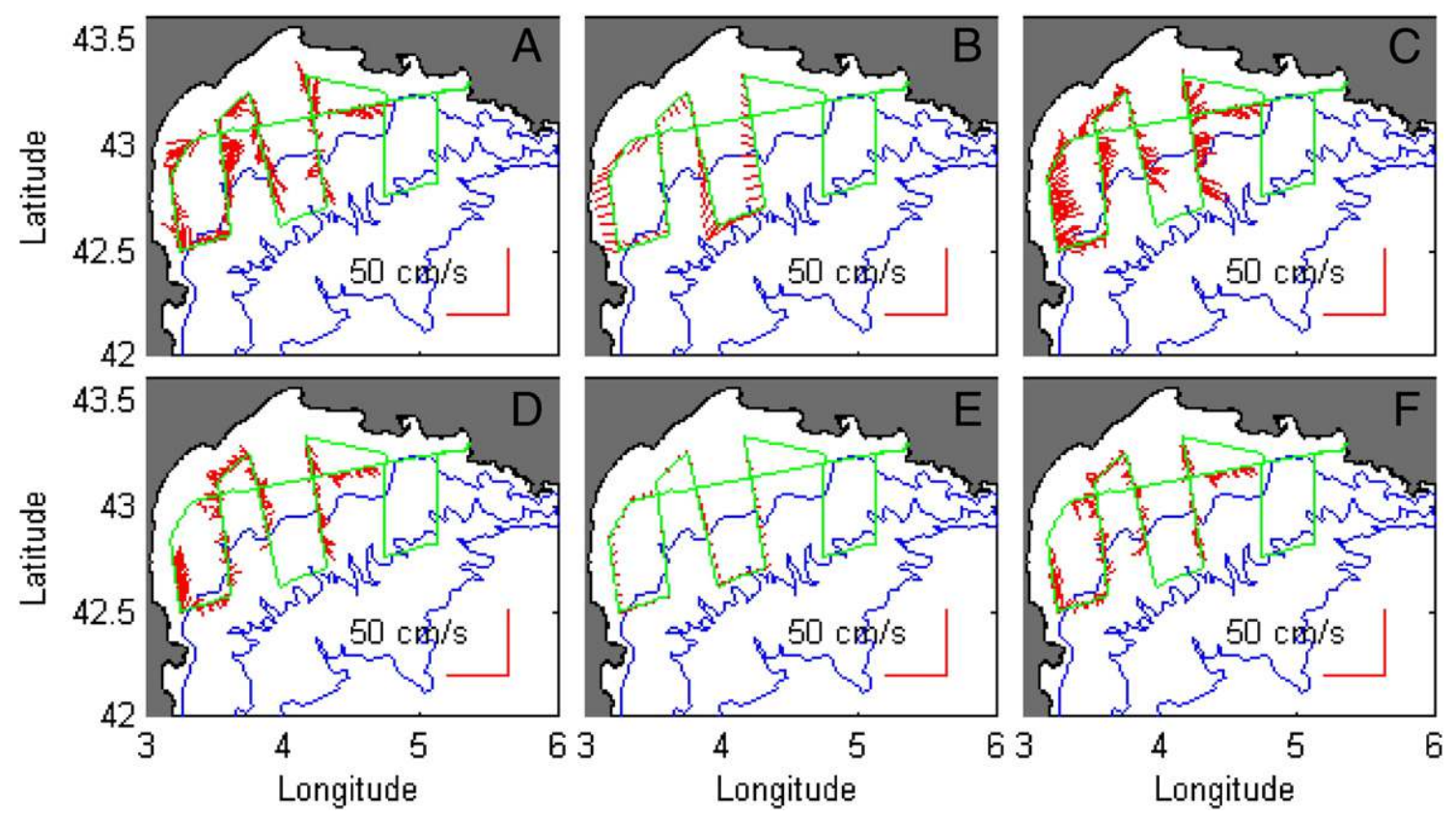

Fig. 3. Maps of the A and D) measured ADCP horizontal currents, B and E) corresponding modelled Inertial Oscillation and C and F) measured currents minus IO during Sarhygol 2, April 2000, from station 2 to station 10. A, B and C are at $12 \mathrm{~m}$ depth; D, E and F at $48 \mathrm{~m}$.

jet on the western side of the GoL and a southeastward current around $43.2^{\circ} \mathrm{N}-4.2^{\circ} \mathrm{E}$ (data not shown). At $42.5^{\circ} \mathrm{N}$, the speed of the coastal jet is $47 \mathrm{~cm} / \mathrm{s}$ (Table 3). Probably due to the previous strong wind event, the depth of the mixed layer ranges from 10 to $40 \mathrm{~m}$, with a bigger variability than during Moogli 2A.

\subsection{Sarhygol 2}

The detailed analysis and removal of the inertial oscillation can be found in Section 2.2. The speed of the eastward current is about $10-20 \mathrm{~cm} / \mathrm{s}$ in the surface layer (Table 3). A southeastward current is detected, around $43.1^{\circ} \mathrm{N}-4.3^{\circ} \mathrm{E}$, between station 1 and station 2 (Fig. 4C).

\subsection{Sarhygol 3}

During Sarhygol 3 (June 13, 16:45-June 15, 15:40, 2000), there are about three to four localized IOs, and not a unique IO as during Sarhygol 2. Two of them are located in the western side of the Gulf of Lion. Since there was not much data crossing the IO areas, it was difficult to evaluate precisely their amplitude and filter them out; so the currents affected by these IOs were simply not plotted. The eastward current corresponds to the southern side of a cyclonic circulation (Fig. 4B), as was observed during Moogli 2A. The eastward current has a maximum speed of about $30 \mathrm{~cm} / \mathrm{s}$ on transects 3-4 (Table 3).

\section{Modelled eastward shelf currents in the Gulf of Lions}

The 3D circulation model Symphonie is a primitive-equation free-surface model (Table 4). It enables us to show the generating processes of some coastal shelf processes. Symphonie is used either to perform academic simulations (idealized wind, maintained constant for 3 days) or realistic simulations (simulations with real atmospheric forcing). The influence of different wind forcings was tested with the academic simulations; while response times and transitional states were studied with realistic simulations.

\subsection{Influence of different wind forcings}

Academic simulations with Symphonie are used in order to find the processes generating the eastward currents. In order to test the influence of common wind forcing on the shelf circulation, academic simulations were carried out starting from realistic conditions encountered early June 2001. First the Symphonie model at $3 \mathrm{~km}$ resolution on the north-western Mediterranean was initialized and forced at the open boundaries by a basin scale model (Demirov and Pinardi, 2002) over the January-June 2001; then nesting

\section{Table 2}

During Sarhygol 2, this table indicates the times at which the stations were reached and the direction (versus the geographic north) of the IO, rotating clockwise at an angular speed of $2 \pi /(17.5 * 60) \mathrm{rad} / \mathrm{s}$, in the surface layer

\begin{tabular}{lcll}
\hline Station & Julian Day & April 2000 & Direction of the IO \\
\hline 2 & 116.17 & $26,4: 05$ & $230^{\circ}$ \\
3 & 116.23 & $26,5: 30$ & $260^{\circ}$ \\
4 & 116.34 & $26,8: 10$ & $315^{\circ}$ \\
5 & 116.43 & $26,10: 20$ & $360^{\circ}$ \\
6 & 116.61 & $26,14: 40$ & $95^{\circ}$ \\
7 & 116.68 & $26,16: 20$ & $120^{\circ}$ \\
8 & 116.88 & $26,21: 10$ & $220^{\circ}$ \\
\hline
\end{tabular}



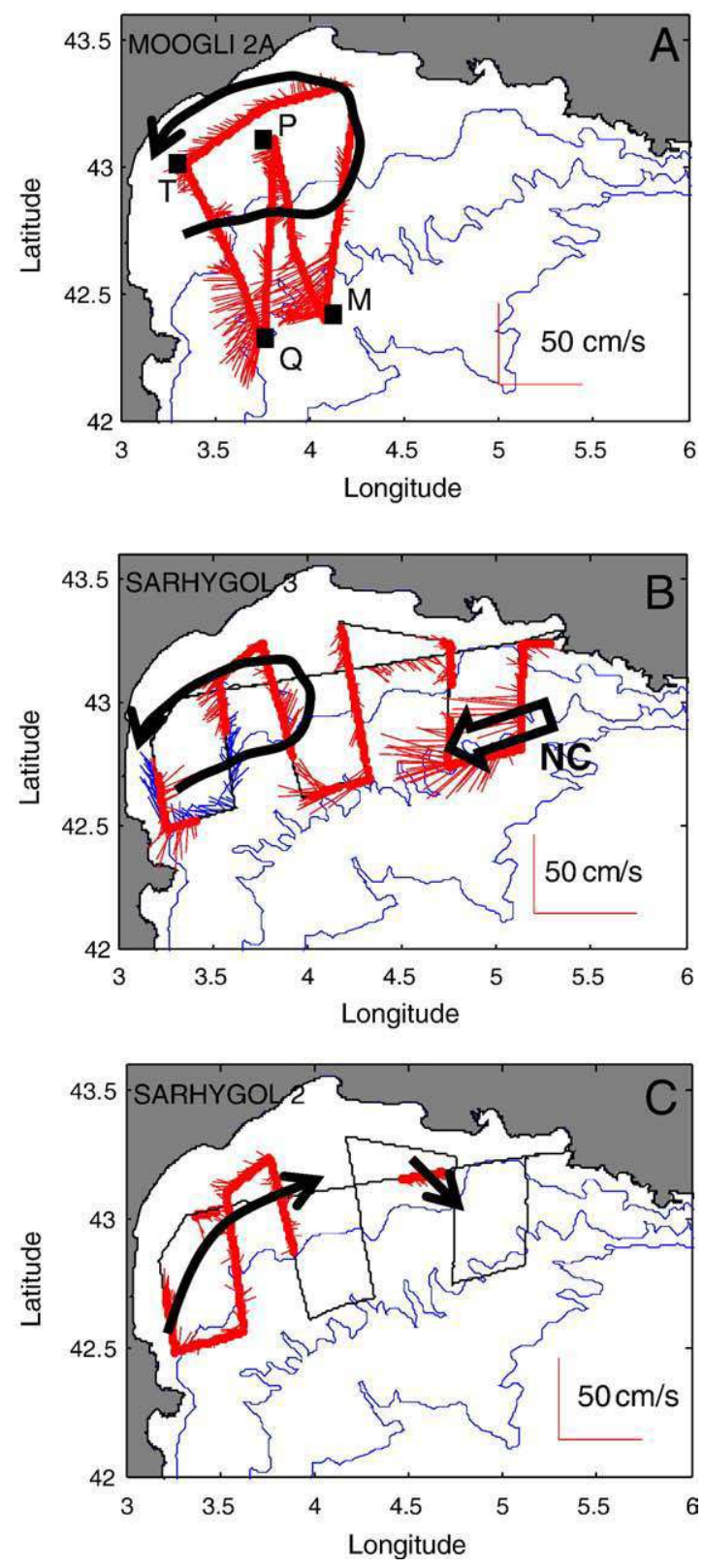

Fig. 4. ADCP currents measured at $48 \mathrm{~m}$ after channelled NW winds during A) Moogli 2A (June 1998) and B) Sarhygol 3 (June 2000); and after homogeneous NW winds during C) Sarhygol 2 (April 2000). Isobaths are indicated at $100 \mathrm{~m}, 1000 \mathrm{~m}$ and $2000 \mathrm{~m}$. Black dotted lines indicate that data are not shown for clarity of the figures. CTD stations are indicated by black dots and their corresponding letters. NC represents the Northern Current.

was done on the Gulf of Lion to obtain a horizontal resolution of $1.5 \times 1.5 \mathrm{~km}$. Starting from the first days of June, this model is run with 3 days of no wind conditions followed by 3 days of the wind forcing to be studied. The results (integrated over the last 0.725 days, corresponding to an inertial period) are then shown below. The characteristics of the five typical wind forcing used in this study are detailed below. The wind forcing has of course been chosen to match typical forcing.
Table 3

For each wind type forcing, this table shows the maximum speed of the eastward current, as well as the location and depth where this speed maximum is measured

\begin{tabular}{lllll}
\hline & & $\begin{array}{l}\text { Maximum } \\
\text { speed }\end{array}$ & Location & Depth \\
\hline Channeled NW & Mo 2 period A & $21 \mathrm{~cm} / \mathrm{s}$ & Transect MP & $24 \mathrm{~m}$ \\
& Sarhygol 3 & $30 \mathrm{~cm} / \mathrm{s}$ & Transect 3-4 & $40 \mathrm{~m}$ \\
Homogeneous NW & Mo 2 period B & $47 \mathrm{~cm} / \mathrm{s}^{*}$ & Transect TR2 & $16 \mathrm{~m}$ \\
& Sarhygol 2 & $10-20 \mathrm{~cm} / \mathrm{s}$ & Transect 5-6 & $12-30 \mathrm{~m}$ \\
& Sarhygol 8 & $26 \mathrm{~cm} / \mathrm{s}$ & Transect 5-6 & $16 \mathrm{~m}$ \\
& & $28 \mathrm{~cm} / \mathrm{s}$ & Transect 5-6 & $8 \mathrm{~m}$ \\
\hline
\end{tabular}

Symbol $\left({ }^{\circ}\right)$ indicates when it is a coastal current, such as on transect 3-4 of Sarhygol 3 and on transect TR2 of Moogli 2. On the latter, the current is also stronger because it is more northward than eastward (symbol *).

\subsubsection{Wind forcing description}

Five types of wind forcing have been used: homogeneous $\mathrm{NW}$, channelled NW, homogeneous $\mathrm{N}$, channelled $\mathrm{N}$ and a combination of channelled NW and N winds (see inserts of Fig. 5). A homogeneous wind is described by its direction $\left(320^{\circ}\right.$ for $\mathrm{NW}$ wind and $0^{\circ}$ for $\mathrm{N}$ wind). The intensity of its stress is equal to $0.5 \mathrm{~N} / \mathrm{m}^{2}$. Its channelled counterpart has the same direction as the homogeneous wind. Its maximum intensity tau $\mathrm{max}_{\max }$ corresponds to the unique intensity of the homogeneous wind $\left(0.5 \mathrm{~N} / \mathrm{m}^{2}\right)$. The channelled wind then decreases linearly on both sides of the wind core (hence its stress curl is constant) until it is nil. The total width across the wind channel is about $150 \mathrm{~km}$. The wind core crosses the coast at latitude $43^{\circ}$ for the NW wind and at longitude $4^{\circ} 50^{\prime}$ for the $\mathrm{N}$ wind. The combined NW and $\mathrm{N}$ channelled winds is the sum of the two previously described forcing.

\subsubsection{Wind-forced shelf circulation}

Each wind forcing leads to a specific shelf circulation pattern (Fig. 5). The sea surface height (SSH) has been superimposed to the currents in order to help explain the shelf circulation, since there is very good agreement between SSH and currents. This study concentrates on eastward currents stronger than $10 \mathrm{~cm} / \mathrm{s}$ and detached from the coast. Such eastward currents are found in the shelf circulation patterns created by three wind forcing:

- A homogeneous NW depresses the surface level throughout the GoL, with a minimum elevation close to the north-

\section{Table 4}

\begin{tabular}{ll}
\hline Symphonie model & References \\
\hline 3D primitive equations & \\
$\begin{array}{ll}\text { For the realistic simulations of Moogli } 2: \text { sigma coordinate } \\
\quad(25 \text { vertical levels; horizontal mesh; } 3.3 \mathrm{~km})\end{array}$ & $\begin{array}{l}\text { (Auclair et al., } \\
2000)\end{array}$ \\
$\begin{aligned} \text { For the academic simulations hybrid sigma-stepped } \\
\quad(40 \text { vertical levels; horizontal mesh; } 1.5 \mathrm{~km})\end{aligned}$ \\
$\begin{array}{ll}\text { Free surface explicitly calculated by decomposition into } \\
\text { internal and external modes }\end{array}$ & $\begin{array}{l}\text { (Marsaleix et al., } \\
2008)\end{array}$ \\
Vertical turbulence 2 nd order closure scheme & (Gaspar et al., \\
Temperature and salinity advection scheme & $\begin{array}{l}1990) \\
\text { (Marsaleix et al., }\end{array}$ \\
\hline
\end{tabular}




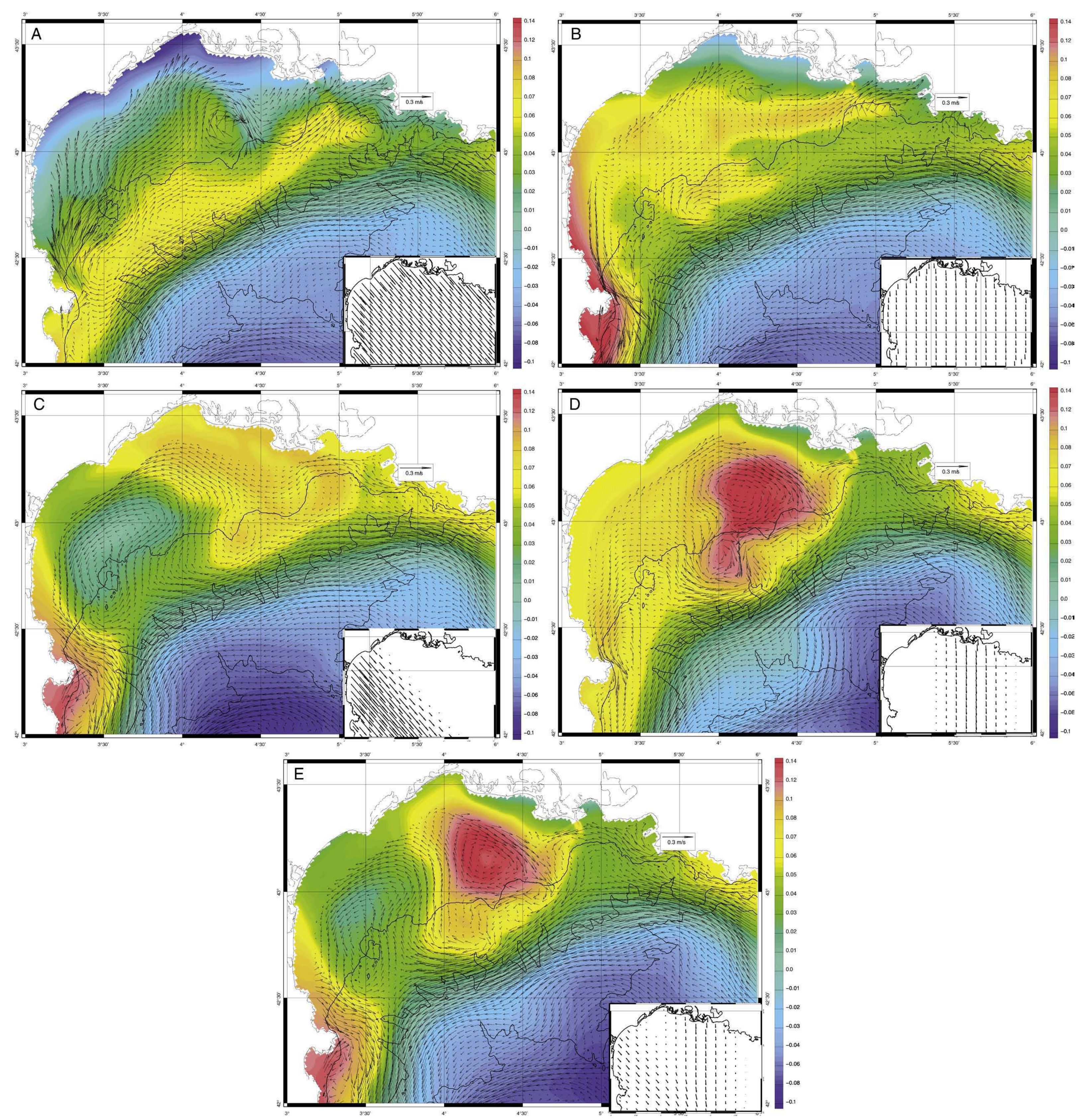


western coast (Fig. 5A). Apart from the south-southwest surface Ekman transport, the resulting circulation is in fact oriented in the opposite direction north-eastward. The water deficit is compensated by a strong current entering the western end, off Cap Creus. From the coast to the slope, this current separates into three branches: a vertically homogeneous coastal current between the coast and the $30-40 \mathrm{~m}$ isobaths, a thick eastward current going along the 60-100 $\mathrm{m}$ isobaths, and a small branch diverging along the $200 \mathrm{~m}$ isobaths, but which joins the main eastward current afterwards. The SSH increases in the wind direction, from the coast until the continental slope. These currents are due to the pressure gradient set up by the wind forcing and acting inside the barotropic Rossby radius (Csanady, 2002). Otherwise, also as explained in Csanady (2002), the area between the coast and the 1st baroclinic Rossby radius presents the characteristics of a coastal upwelling forced by offshore winds (data not shown).

A strong southeastward current is observed off the northern coast at longitude $4^{\circ} 20^{\prime}$. In fact, this current turns into a small anticyclonic eddy. Otherwise, the striking feature of this shelf circulation is the intrusion of water at Cap Creus. Since the shelf is particularly narrow at this end of the gulf, the water enters the shelf following the Cap Creus canyon (the closer to Cap Creus on Fig. 1).

- When the NW wind is channelled, the surface pressure field is not characterised by a positive gradient offshore along the wind direction but by a low pressure on the western side of the GoL (Fig. 5C). This low pressure, induced by the positive wind stress curl of the channelled $\mathrm{NW}$, creates an elongated cyclonic circulation in the western side of the gulf. The south-eastern loop of this cyclonic circulation is the eastward current presently studied. Current offshore of Cap Creus is directed to the south. In opposition to the homogeneous NW wind, the channelling of the NW induces a wind stress curl which most important consequence is the reversal of the coastal current. Indeed the coastal current is south-westward instead of north-eastward during homogeneous NW. In consequence, isopycnals close to the coast exhibit downwelling features (data not shown), in opposition to the case of the homogeneous NW. In opposition to the upwelling observed along the whole western coast of the gulf (up to the Rhone River) during homogeneous NW, the downwelling is localized. It occurs along the coast where the wind forcing is present, and especially where the SSH is higher at the coast than offshore (between latitude $42^{\circ} 30^{\prime}$ and $43^{\circ}$ ).

- A homogeneous $\mathrm{N}$ wind creates a weak counter circulation covering nearly the whole shelf of the GoL (Fig. 5B). The eastward current is strong only south of the $100 \mathrm{~m}$ isobath from longitude $3^{\circ} 45^{\prime}$ to $4^{\circ} 30^{\prime}$. In fact this current corresponds to intrusions of the Northern Current on the shelf. The main intrusion is located around long. $3^{\circ} 45^{\prime}$ and lat. $42^{\circ} 45^{\prime}$; a secondary one is located more east, around long. $4^{\circ} 25^{\prime}$ and lat. $43^{\circ}$. In opposition to the case of the homogeneous NW, the current offshore Cap Creus goes south.

These three types of winds generate eastward currents on the shelf but with very different associated circulation patterns. Only the first two cases of wind forcing are studied in detail in the following sub-section on sensitivity tests since measured data corroborate their results.

Shelf circulations obtained with other wind forcing (Fig. 5D and E) are shown to prove that eastward currents are not always present and appear only with specific wind forcing. Indeed, during channelled $\mathrm{N}$ wind, currents are very complex on the shelf (Fig. 5D). A kind of bipolar anticyclonic circulation can be detected in the center of the gulf. In the western part, currents are southward. In the case of simultaneous NW and $\mathrm{N}$ winds (each channelled in its respective area), features of both wind forcing, when they were acting alone (Fig. 5C and D), can still be detected in the gulf, with some modifications. Indeed a cyclonic gyre can be observed on the western side of the GoL (Fig. 5E). But, instead of being elongated in a southwest-northeast direction, as during the channeled NW forcing (Fig. 5C), this cyclonic gyre is restrained to the west side of the GoL by the channelled $\mathrm{N}$ wind east of the GoL. Hence the gyre is elongated in a more south-north direction and the eastward current is not as important as in the case of the channeled NW. Otherwise, the bipolar anticyclonic circulation, observed during channelled $\mathrm{N}$ wind, is also present but with a much weaker southern component.

\subsubsection{Sensitivity tests}

It has just been shown that the wind characteristics have major consequences on the shelf circulation. For example, both homogeneous and channelled NW winds induce eastward currents in the middle of the western shelf but with very different circulations along the coast. Hence, sensitivity tests have been done to evaluate the role of the different wind parameters chosen to represent real wind forcing. As mentioned before, the modelled NW comes from $320^{\circ}$ and, when it is channelled, its core crosses the coast at latitude $43^{\circ} \mathrm{N}$. Sensitivity tests varying its direction, its width, its position or simulating it with a curved trajectory (for example, curving slightly to the south by shifting from $320^{\circ}$ inland to $340^{\circ}$ in the $\mathrm{GoL}$ ) have been done. They show that the circulation is generally identical to the one presented here when the position is shifted south or with the curved trajectory. The biggest differences are found when the direction or width of the NW wind is changed. When the direction is shifted from $320^{\circ}$ to $295^{\circ}$, a small anticyclonic circulation, created by the negative wind stress curl southwest of the wind channel, has space to settle between the coast and the wind channel. Northeast of the wind channel, the positive wind stress curl still creates the cyclonic circulation of the classical case but less elongated.

The width of the NW has also been varied. It is interesting to note that for a width 1.5 times larger than the $150 \mathrm{~km}$ of the channelled NW, the circulation is practically unchanged (case $W^{*} 1.5$ ). While, if the width is 3 times larger (case $W^{*} 3$ ), the shelf circulation looks closer to the circulation generated by a homogeneous NW (Fig. 5A). In the case $W^{*} 3$, the wind forcing (from its maximum to half the maximum value) covers about $75 \%$ of the GoL, but has, of course, a much weaker wind stress curl. Going from the classical width $(W)$ to $W^{*} 1.5$, and then $W^{*} 3$, the wind stress curl decreases and a north-eastward current progressively develops along the western coast of the GoL. This north-eastward coastal current widens $(7 \mathrm{~km}$ for $W^{*} 1.5-15 \mathrm{~km}$ for $W^{*} 3$ ) and prevents the cyclonic gyre of the channelled NW situation to settle. In the case of the homogeneous NW, this north-eastward current corresponds 
to the coastal branch described in Section 4.1.2. This exhibits the direction reversal of the coastal current mentioned above, accompanied with the disappearance of the coastal downwelling replaced by the coastal upwelling.

These sensitivity tests are very informative and show how important it is, for efficient modelling, to choose the right wind parameters, i.e. parameters that represent realistic forcing.

\subsubsection{Interpretation of the measured $A D C P$ data}

These modelled outputs are now used in order to synthesize the various cases of shelf circulation measured during the cruises and described in Section 3. According to the wind forcing that occurred either just before or during the cruises (Table 1), the five cases of measured eastward currents can be explained as due to:

- the homogeneous NW for Moogli 2B, Sarhygol 2 and Sarhygol 8,

- the channelled NW for Moogli 2A and Sarhygol 3.

Indeed there is a very good agreement between measured and modelled currents. During homogeneous NW, the eastward current is present in the western GoL (Figs. 3, 4C and 5A). Even the southeastward current - corresponding to the eastern part of the small modelled anticyclonic gyre of the center of the gulf (Fig. 5A) - has been measured (see between stations 1 and 2 of Fig. 3A and C). During channelled NW, the eastward current corresponds to the southern part of a cyclonic circulation indicated by arrows in the measured data (Fig. 4A and B) and clearly visible on the model output (Fig. 5C).

Some differences are observed between the measured and the modelled currents. For example, in the upper layer, the measured eastward currents are stronger than the ones modelled with these academic simulations. It seems that this could be explained by a strong Ekman circulation in the modelled surface layer (refer to the discussion in Section 5). This could be due to the wind used for this academic simulation being too strong and constant. So modelling with realistic forcing was also done to confirm the obtained results.

\subsection{Transitional states and response times}

Realistic simulations with Symphonie are undertaken in order first to confirm the results obtained with the academic simulations and second to provide additional information that academic simulations could not simulate, such as response times to wind forcing or transitional states (e.g., transitions between shelf circulations patterns, transitional IOs...). Symphonie is used with a horizontal resolution of $3 \times 3 \mathrm{~km}$ forced by the outputs of the Météo-France weather-forecast model Aladin (Dufau-Julliand et al., 2004). Only the results obtained from the realistic simulations of the Moogli 2 cruise will be shown here. This study concentrates on the same two periods as the ones defined in Section 1.2: period A (June 6-8, 1998) and period B (June 14-15, 1998). The simulated currents are interpolated (separately in time and in space) along the ship track in order to be compared to the measured currents. Realistic simulations often find features comparable to in situ data but at different locations or shifted in time. Here, measured data and simulated results can be compared at exactly the same time and locations, and the agreement is very good (Fig. 6).

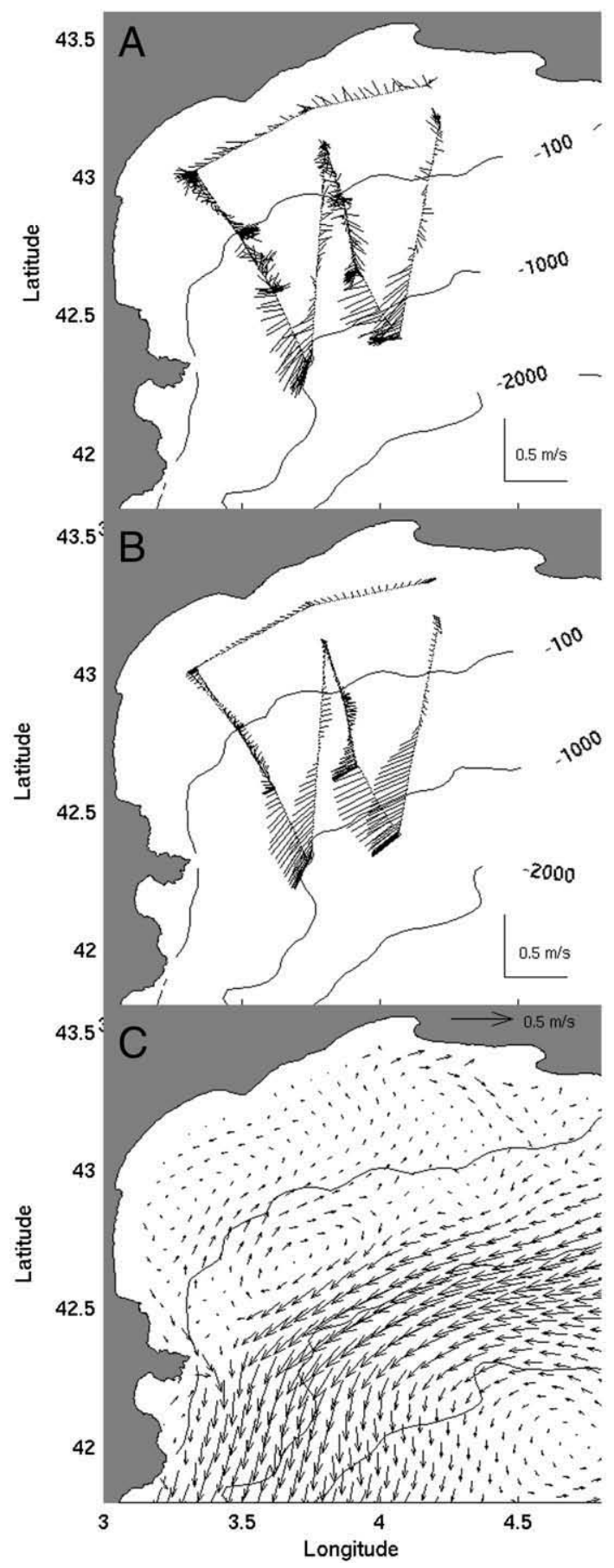

Fig. 6. A) Measured ADCP currents at $32 \mathrm{~m}$ along the ship track during Moogli $2 \mathrm{~A}$ (June 6,15:50-June 8, 21:45), B) modelled currents at $32 \mathrm{~m}$ interpolated in time and space to follow the ship track during Moogli 2A; C) modelled currents at $30 \mathrm{~m}$ on June $8-6: 00$.

Response times to wind forcing can be determined with the realistic simulations. Indeed, during Moogli 2A, the NW was channelled from June 7, 6:00 until June 7, 15:00; then it spreads throughout the gulf and can be considered 
homogeneous starting on June 7, 18:00 (Table 1; Fig. 7). The modelled current shifted to:

- the channelled NW pattern of circulation starting on June 7, 15:00 (between Fig. 7F and $\mathrm{H}$ ), about $9 \mathrm{~h}$ after the channelled wind started,
- the homogeneous NW pattern of circulation starting on June 8, 6:00 (Fig. 7L), about $12 \mathrm{~h}$ after the wind was considered homogeneous.

During Moogli 2B, the currents correspond to the ones obtained with a homogeneous NW (data not shown). The

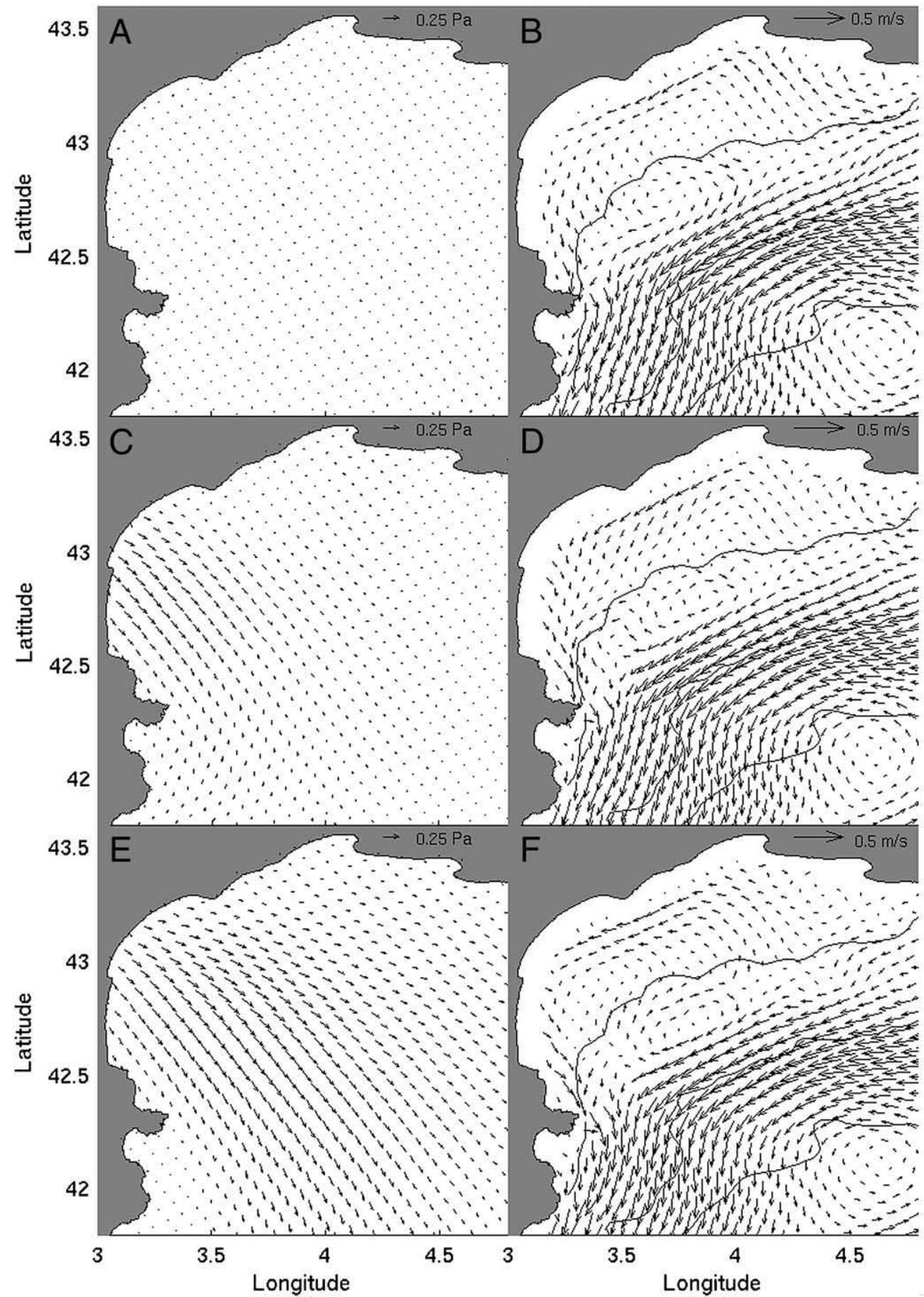

Fig. 7. a Temporal series of horizontal sections of left) wind, right) currents at $32 \mathrm{~m}$ during Moogli 2A. The exact dates are: A and B: June $7-0: 00, C$ and D: June $7-$ 6:00, E and F: June $7-12: 00$. b Temporal series of horizontal sections of left) wind, right) currents at $32 \mathrm{~m}$ during Moogli $2 \mathrm{~A}$. The exact dates are: $\mathrm{G}$ and $\mathrm{H}$ : June 7 , 18:00, I and J: June $8-0: 00, K$ and L: June $8-6: 00$. 

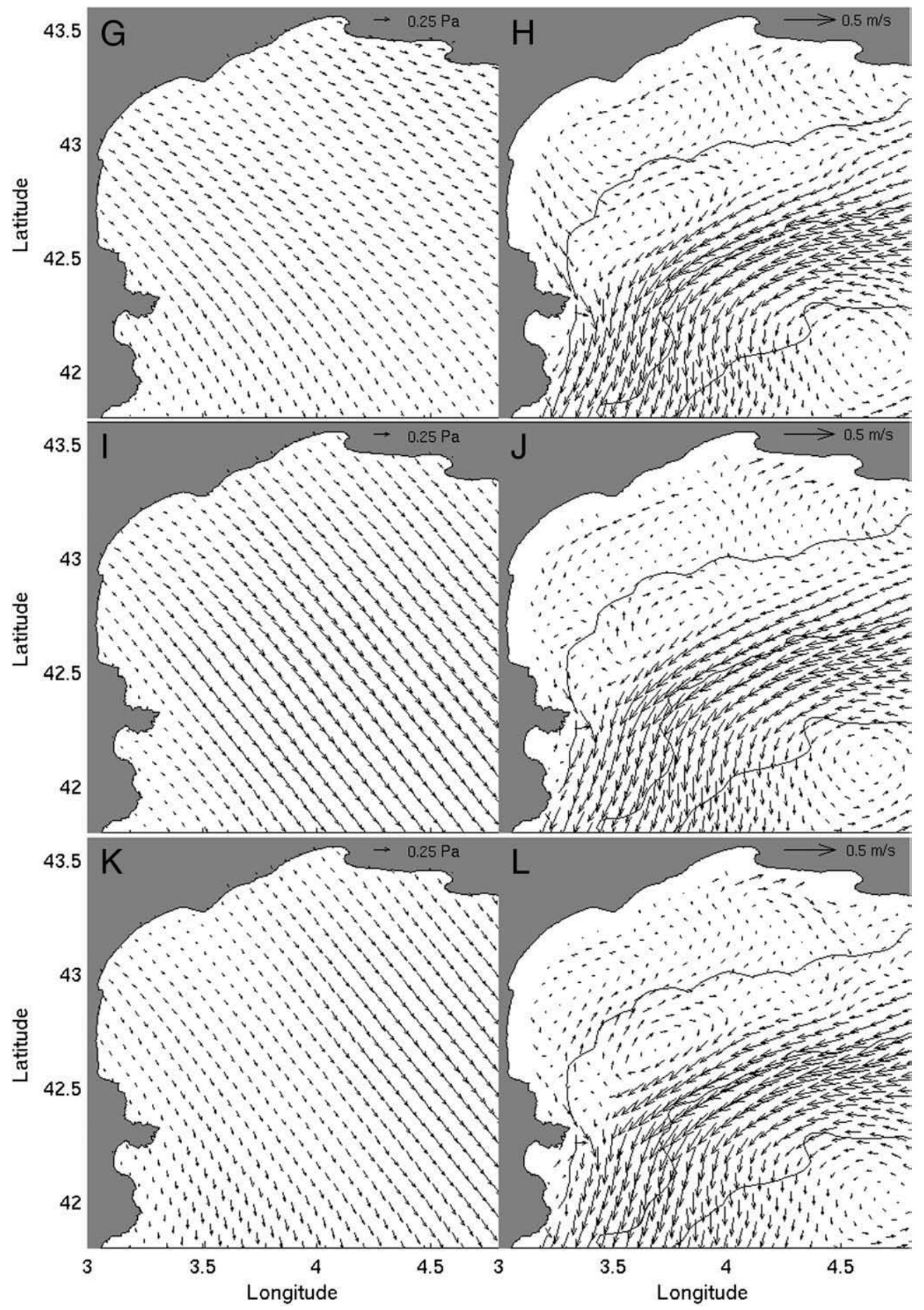

Fig. 7 (continued).

situation is identical as in period $\mathrm{A}$, in the sense that the shelf circulation pattern of June 14 corresponds in fact to the wind forcing of the previous days (June 12-13, see Table 1). The circulation pattern of the homogeneous NW settled about $12 \mathrm{~h}$ after the beginning of the wind forcing.
These two examples show that the circulation on the shelf has a time response of about $12 \mathrm{~h}$. This should not be interpreted wrongly: strong winds can have nearly immediate effects on surface waters; but it takes about the time estimated above for a shelf pattern of circulation to get established down to a depth of 30-40 m. Nonetheless, this 
time response may not correspond to the time necessary for a complete adjustment to the wind forcing. Indeed, some of the current data measured after June 7, 18:00 still agree with the circulation pattern of the channelled $\mathrm{NW}$, wind forcing that has stopped $30 \mathrm{~h}$ before. Hence caution need to be taken in using these time response estimations and further study should be undertaken on the subject.

\section{Characteristics of the currents and discussion}

Three main characteristics of these eastward currents are presented: their barotropic characteristic, their amplitude, and their locations.

During stratified conditions, one often observes different currents in the top and bottom layer. Here, one of the striking facts with these eastward currents is that they are barotropic
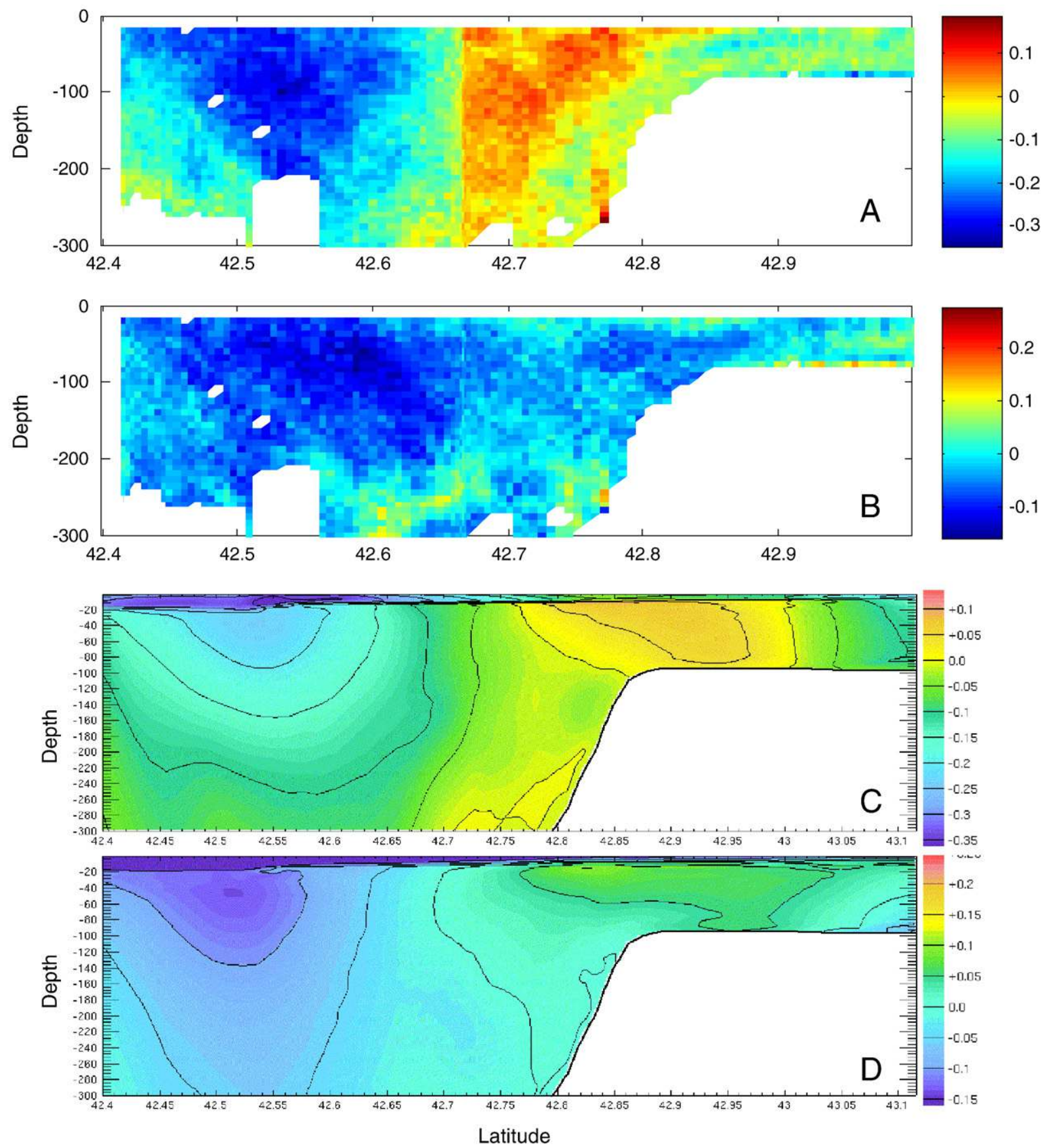

Fig. 8. Vertical section of horizontal currents A and C) west-east component (+ to the east), B and D) south-north component (+ to the north); A and B correspond to measured ADCP currents, $C$ and D to Symphonie currents modelled with the academic channelled NW. The data were measured during Moogli 2A (June 6, 21:50 to June 7, 3:15); the section corresponds to transect MP, i.e. between CTD stations M and P indicated on Fig. 4A. The eastward current is located between longitudes $42.68^{\circ} \mathrm{N}$ and $42.83^{\circ} \mathrm{N}$ 
currents. These eastward currents are detected down to either the bottom or the limit of the ADCP detection range (Fig. 8). They are also detected up to the surface. Indeed, surface data, such as chlorophyll concentration mapped by satellite, agree with the ADCP measured currents, that start either at $16 \mathrm{~m}$ depth for Moogli 2 or at $8 \mathrm{~m}$ depth for Sarhygol 2 and 3 (data not shown) or the modelled currents (Fig. 9). The influence of the distal plume of the Rhone River can be tracked by its high chlorophyll signature. On the transect between stations 7 and 8 , the horizontal narrowing of the high chlorophyll water mass, visible in the bottle neck pattern between the coast and offshore, is interpreted as due to the north-eastward current present there.

Nonetheless the influence of an Ekman layer circulation is sometimes noticeable. During Sarhygol 3, for example, the current below the surface layer is clearly to the east along transects 3-4 and to the northeast along transects 7-8. But, in fact, in the surface layer (down to $15 \mathrm{~m}$ ), the measured current along transects 7-8 is southeast instead of northeast (data not shown). This is due to the Ekman circulation that adds a southward-south-westward component to the barotropic north-eastward current. Obtaining a current with a southward component in the surface layer means that the amplitude of the Ekman surface current is bigger than the one of the north-eastward current. This is confirmed by the academic modelled results previously presented. Indeed, in the modelled case, the NW comes from $320^{\circ}$ hence the Ekman circulation is south-westward (towards $230^{\circ}$ ) and opposed to the north-eastward current. Since the model results clearly show a southeastward current in the top layer, this confirms that the amplitude of the Ekman surface current is larger than the one of the north-eastward current. During the channelled NW simulation, the Ekman layer is clearly detected from the surface down to $20 \mathrm{~m}$ (Fig. $8 \mathrm{C}$ and D). The thickness of the Ekman surface layer is in very good agreement with the in situ data. Since this Ekman layer clearly gets thinner toward the coast, it is not surprising that its effect could not be felt in the measured currents at $8 \mathrm{~m}$ depth along transects 3-4. Moreover, in our case of a sloping bottom, the long-shore transport should be zero at the coast and would only asymptotically reach the value of the classical Ekman transport further from the coast (Csanady, 2002).
During Moogli 2A, the maximum speed of the eastward current is $21 \mathrm{~cm} / \mathrm{s}$ (transect QT, Fig. 4A, Table 3). During Sarhygol 3, the maximum speed of the eastward current is around $30 \mathrm{~cm} / \mathrm{s}$ (transects 3-4, Fig. 4C). So the average maximum speed of the eastward currents generated by channelled NW is about $25 \mathrm{~cm} / \mathrm{s}$. During Sarhygol 2, the maximum amplitude, once the IO amplitude is retrieved, is around 10$20 \mathrm{~cm} / \mathrm{s}$ (there are uncertainties about this speed range since the IO amplitude is hard to estimate). During Sarhygol 8, the maxima are above $25 \mathrm{~cm} / \mathrm{s}$, in the surface layer above $15 \mathrm{~m}$, on both transects 3-4 and 5-6. Between 15 and $25 \mathrm{~m}$, the average speed in the eastward current is still $20 \mathrm{~cm} / \mathrm{s}$. During Moogli $2 \mathrm{~B}$, north of Cap Creus, the current reaches values of $47 \mathrm{~cm} / \mathrm{s}$. But, at this location, the current is coastal and north-northeastward rather than eastward and hence cannot be taken into account as representative of eastward currents. So the average maximum speed of the eastward currents generated by homogeneous NW is also estimated to be about $25 \mathrm{~cm} / \mathrm{s}$. Hence, these few measured examples show that the eastward currents, generated whether by channelled NW or by homogeneous NW, have maxima around $25 \mathrm{~cm} / \mathrm{s}$. In a gulf environment, these currents are non negligible and can have important impacts, among others, on larva dispersion.

In the academic simulation outputs, the amplitude maximum of the eastward current created by the channelled $\mathrm{NW}$ is about $15 \mathrm{~cm} / \mathrm{s}$ below the surface layer. In the case of the homogeneous NW, the eastward current is important at depth (reaching $30 \mathrm{~cm} / \mathrm{s}$ at $50 \mathrm{~m}$ depth). Further comparison between the eastward current amplitudes obtained with these two wind forcing are not attempted since the wind stress is in average different for the two cases (different wind stress curl). Otherwise, in both cases, the eastward current is not detectable in the upper layer due to the presence of the contrary wind Ekman circulation.

The locations of the eastward currents differ slightly in the two cases detailed above. In the case of the channeled NW, the eastward current follows closely the $100 \mathrm{~m}$ isobath (Fig. 4). In the case of the homogeneous NW, the eastward circulation is subdivided in two branches over the shelf and one over the slope. The most coastal one is rather homogeneous as the barotropic component of the pressure gradient dominates over the baroclinic one and the wind acceleration

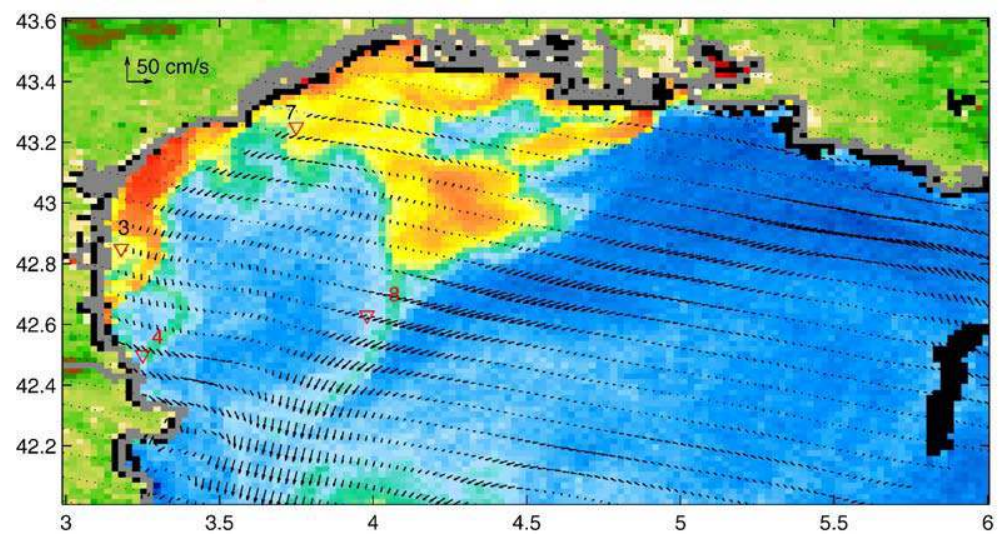

Fig. 9. SeaWiFs chlorophyll concentration (courtesy JRC web site) of June 16, 2000 during Sarhygol 3. Modelled ADCP horizontal currents at 48 m during channelled tramontane are superimposed. Specific stations are indicated. 
in these shallow waters $(20 \mathrm{~m})$. Over the mid-shelf, the barotropic pressure gradient is lower and the eastward current is clearly visible only below the Ekman layer.

Such unexpected barotropic shelf-edge currents, opposed to the along-slope circulation, influence the shelf circulation and can have an effect on the residence time of waters in the Gulf of Lion by trapping and mixing water masses in previously unconsidered ways. They also affect the spatial distribution of biomass on the shelf and, hence, may have important consequences on the shelf ecosystem, and the various human activities linked to it.

The results obtained during this study were compared with the ones of the Gulf of Papua, with the Coral Sea Coastal Current replacing the Northern Current. Geographically, the two gulfs are oriented identically (coast to the north and slope current to the south). But, in opposition to the Gulf of Lion, the Gulf of Papua is in the southern hemisphere. Modelling runs were done for the Papua dominant winds: homogeneous westward trades, north-westward winds and southeastward winds (Wolanski et al., 1995). Wolanski et al. obtained counter-currents on the Papua shelf during westward and north-westward winds. This agrees with our result for homogeneous northwesterlies. Nonetheless they mentioned discrepancies between their simulations and the observations interpreted as due to the homogeneity of the wind field used as model forcing and inadequate to reproduce the reality. Indeed the present study shows how important the curl of the wind stress is. In the north-western Black Sea, Oguz and Besiktepe (1999) indicated that the presence of a cyclonic circulation should be further studied to be potentially linked with fresh water discharge or northeasterlies. Modelling study showed the importance of the seasonal cycle of the wind stress (Korotaev et al., 2003). Counter-currents were apparent at different locations (Beckers et al., 2002). But no specific study, comparable to the present one, has been done on the link of wind stress curl and counter-currents.

In the Gulf of Lion, during winter non stratified conditions, eastward currents have been measured after strong northwesterly winds, both channelled and homogeneous (Petrenko, 2003), and have been reproduced with Symphonie simulations (Estournel et al., 2003). Circulations created by northwesterlies are quite similar in stratified and non stratified conditions; while the ones created by northerlies differ. No simple explanation has been found, so this would require further in situ measurements and modelling studies.

\section{Conclusions}

This study shows that barotropic eastward currents measured in the Gulf of Lion during stratified conditions are associated with specific wind forcing. A homogeneous northwesterly wind creates a strong coastal jet north of Cap Creus. This jet follows the coast and then goes eastward north of the $100 \mathrm{~m}$ isobath. During this wind forcing, the flow is northward offshore of Cap Creus, inducing an intrusion in the Gulf of Lion. The wind stress curl of a channeled northwesterly wind creates an elongated cyclonic circulation in the western part of the Gulf of Lion. The south-eastern part of this cyclonic circulation is a barotropic eastward current detected west of longitude $4.5^{\circ} \mathrm{E}$. A homogeneous $\mathrm{N}$ wind creates a counter circulation covering nearly the whole shelf of the Gulf of Lion. The eastward current is particularly strong south of the $100 \mathrm{~m}$ isobath from longitude $3^{\circ} 45^{\prime}$ to $4^{\circ} 30^{\prime}$. During the two latter wind forcings, in opposition to the case of the homogeneous NW, the current offshore Cap Creus goes southeast, then south.

These eastward currents are barotropic with a maximum amplitude of about $25 \mathrm{~cm} / \mathrm{s}$ on the western side of the gulf. The barotropic characteristic of these currents was quite unexpected in summer stratified conditions.

In fact, even the presence of these barotropic eastward currents was rather unsuspected since they are mentioned only anecdotally in a few literature articles. These eastward currents could lead to an increase in water residence time in the Gulf of Lion, as is probably the case during homogeneous northwesterlies. Indeed the homogeneous northwesterlies induce a rare water intrusion at the southwestern end of the Gulf of Lion. Since the shelf is particularly narrow at this end of the gulf, the Cap Creus canyon has a major role in the water budget of the gulf. Changing the residence time on the shelf can have non negligible repercussions on the primary production on the shelf and, hence, on total biogeochemical budgets of the gulf, as well as halieuthic activities.

\section{Acknowledgements}

This research was supported by the French Programme National d'Environnement Côtier (PNEC) and Programme Atmosphère et Océan à Moyenne Echelle (PATOM).

\section{References}

Auclair, F., Marsaleix, P., Estournel, C., 2000. Sigma coordinate pressure gradient errors: evaluation and reduction by an inverse method. J. Atmos. Ocean. Technol. 17, 1348-1367.

Bourrin, F., Durrieu de Madron, X., 2006. Contribution to the study of coastal rivers and associated prodeltas to sediment supply in the Gulf of Lions (NW Mediterranean Sea), V\&M. Life Environ. 56 (4), 307-314.

Beckers, J.M., Gregoire, M., Nihoul, J.C.J., Stanev, E., Staneva, J., Lancelot, C., 2002. Modelling the Danube-influenced north-western Continental Shelf of the Black Sea. I: hydrodynamical processes simulated by 3-D and box models. Estuar. Coast. Shelf Sci. 54 (3), 453-472.

Chereskin, T.K., Levine, M.D., Harding, A.J., Regier, L.A., 1989. Observations of near-inertial waves in Acoustic Doppler Current Profiler measurements made in the Mixed Layer Dynamics Experiment. J. Geophys. Res. 94 (C6), 8135-8145.

Demirov, E., Pinardi, N., 2002. Simulation of the Mediterranean Sea circulation from 1979 to 1993: Part I. The interannual variability. J. Mar. Syst. 33-34, 23-50.

Dufau-Julliand, C., Marsaleix, P., Petrenko, A., Dekeyser, I., 2004. Threedimensional modeling of the Gulf of Lion's hydrodynamics (northwest Mediterranean) during January 1999 (MOOGLI3 Experiment) and late winter 1999: Western Mediterranean Intermediate Water's (WIW's) formation and its cascading over the shelf break. J. Geophys. Res. 109 (C11), C11002.

Durrieu de Madron, X., Abassy, A., Heussner, S., Monaco, A., 2000. Particulate matter and organic carbon budgets for the Gulf of Lions (NW Mediterranean). Oceanologica acta 23 (6), 717-730.

Estournel, C., Kondrachoff, V., Marsaleix, P., Vehil, R., 1997. The plume of the Rhone: numerical simulation and remote sensing. Cont. Shelf Res. 17 (8), 899-924.

Estournel, C., Durrieu de Madron, X., Marsaleix, P., Auclair, F., Julliand, C., Vehil, R., 2003. Observation and modelisation of the winter coastal oceanic circulation in the Gulf of Lions under wind conditions influenced by the continental orography (FETCH experiment). J. Geophys. Res. 108 (C3), 8059.

Frouin, R., Fiuza, A.F.G., Ambar, I., Boyd, T., 1990. Observations of a polaward surface current off the coasts of Portugal and Spain during winter. J. Geophys. Res. 95 (C1), 79-91. 
Gaspar, P., Gregoris, Y., Lefevre, J.M., 1990. A simple eddy kinetic energy mode for simulations of the oceanic vertical mixing tests at station Papa and long-term upper ocean study site. J. Geophys. Res. 95, 179-193.

Hetland, R., Hsueh, Y., Yuan, D., 2001. On the decay of a baroclinic jet flowing along a continental slope. J. Geophys. Res. 106 (C9), 19,797-19,807.

Korotaev, G., Oguz, T., Nikiforov, A., Koblinsky, C., 2003. Seasonal, interannual, and mesoscale variability of the Black Sea upper layer circulation derived from altimeter data. J. Geoph. Res. 108 (C4).

Ludwig, W., Meybeck, M., Abousamra, F., 2003. Riverine transport of water, sediments, and pollutants to the Mediterranean Sea. UNEP MAP Technical Report, Series, 141. UNEP/ MAP, Athens. p. 111

Marsaleix, P., et al., 2008. Energy conservation issues in sigma-coordinate free-surface ocean models. Ocean Modelling 20 (1), 61-89.

Masson, D., Cummins, P.F., 1999. Numerical simulations of a bouyancy-driven coastal countercurrent off Vancouver Island. J. Phys. Oceanogr. 29 (3), 418-435.

Millot, C., 1990. The Gulf of Lion's hydrodynamics. Cont. Shelf Res. 10 (9-11), $885-894$

Millot, C., 1992. Are there major differences between the largest mediterranean seas? A preliminary investigation. Bull. Inst. Océanogr. (Monaco) 11, $3-25$.
Millot, C., 1999. Circulation in the western Mediterranean Sea. J. Mar. Syst. 20, 423-442.

Oguz, T., Besiktepe, S., 1999. Observations on the Rim Current structure, CIW formation and transport in the western Black Sea. Deep-Sea Res. I 46, 1733-1753.

Petrenko, A.A., 2003. Circulation features in the Gulf of Lions, NW Mediterranean Sea; importance of inertial currents. Oceanol. Acta 26, 323-338.

Petrenko, A., Leredde, Y., Marsaleix, P., 2005. Circulation in a stratified and wind-forced Gulf of Lions, NW Mediterranean Sea: in-situ and modeling data. Cont. Shelf Res. 5, 5-27.

Relvas, P., Barton, E.D., 2002. Mesoscale patterns in the Cape Sao Vicente (Iberian peninsula) upwelling region. J. Geophys. Res. 107 (C10) 3164-23.

Thunus, V., 1996. Modélisation à méso-échelle de l'hydrodynamique et du transport de particules en milieu marin semi-ouvert. Application au Golfe du Lion. Université de Neuchâtel. p. 143.

Wolanski, E., Norro, A., King, B., 1995. Water circulation in the Gulf of Papua. Cont. Shelf Res. 15 (2/3), 185-212. 